\title{
The effect of organizational culture on quality of accounting information: Mediating the role of accounting information system
}

\author{
Quang Linh Huynh ${ }^{a^{*}}$
}

${ }^{a}$ Ho Chi Minh City University of Food Industry, Vietnam

\section{CHRONICLE ABSTRACT}

\section{Article history:}

Received: February 26, 2021

Received in revised format:

April 262021

Accepted: April 28, 2021

Available online:

April 29, 2021

Keywords:

Accounting information system

Accounting information quality

Organizational culture

Mediating effect

\begin{abstract}
Organizational culture has been documented as a driving force of the acceptance of accounting information systems in business and accounting information quality; whereas accounting information quality as a causation of the acceptance of accounting information systems in business. The acceptance of accounting information systems in business could mediate the causal connection from organizational culture to accounting information quality. Nonetheless, nearly none of the projects has assessed the mediating role of the acceptance of accounting information systems in business, especially in Vietnam as a developing country. The current research tries to investigate the mediation of the acceptance of accounting information systems in business in the research model. The findings indicate that the acceptance of accounting information systems in business transmits part of the influence of organizational culture on accounting information quality. The current research could make some contributions to how executives ought to decide on organizational culture as well as on the acceptance of accounting information systems in business so that their organizational performance could be improved.
\end{abstract}

\section{Introduction}

The information of accounting has big effects on organizational performance. Widespread usage of accounting information systems in business could lead to better financial and managerial decisions for a company. In emerging economies, those decisions are extremely costly that makes big if such decisions are poor (Soto-Acosta et al., 2016). Thus, it is indispensable to improve accounting information quality by using the system of accounting information in business that provides a competitive advantage to firms and finally enhances organizational performance. Organizational culture is regarded as a standard for all organizational activities by which the goals, vision, mission and plans of the firm are reflected in organizational culture (Kwarteng \& Aveh, 2018). Thus, the culture of organization has actual effects on organizational efficiency. According to Indeje and Zheng (2010) in order for accounting information systems in business to operate efficiently, properly and accurately, firms need to base their business activities on the culture of organization. In addition, when the system of accounting information runs well, it can deliver qualified accounting information for business that motivates organizational operation more effectively (Ha, 2020). Prior research has suggested organizational culture could determine the acceptance of accounting information systems in business as well as accounting information quality that in turn is decided by the acceptance of accounting information systems in business (Al-Hiyari et al., 2013; Azmi \& Sri, 2015; Suzan et al., 2020; Fitrios, 2016; Ha 2020; Azmi \& Sri, 2015; Nguyen \& Nguyen, 2020).

* Corresponding author.

E-mail address: linhhq@hufi.edu.vn (Q. L. Huynh)

(C) 2021 by the authors; licensee Growing Science, Canada doi: $10.5267 /$ j.ac. 2021.4 .030 
Based on Baron and Kenny (1986), it may propose the acceptance of accounting information systems in business could intercede between organizational culture and accounting information quality. This mediation may be an omitted tie between these factors that has been unnoticed in earlier research. Numerous scholars have investigated the associations among organizational culture and managerial systems in business; nevertheless, they have inclined to focus on developed countries, which are different than those in Vietnam (Huynh et al. 2020). To my knowledge, nearly no studies in Vietnam have been performed on the mediation of the acceptance of accounting information systems in business on the correlation between organizational culture and accounting information quality. Hence, the intention of the current study is to analyze the effects of organizational culture on the acceptance of accounting information systems in business and accounting information quality; especially it tries to explore the mediating influence of accounting information systems in the causal connection from organizational culture to accounting information quality in Vietnamese firms.

\section{Literature Review and Research Hypotheses}

According to Romney et al. (2015), the system of accounting information is a method of collecting, keeping and handling accounting and financial data which is helpful for managers to make business decisions. The system of accounting information is normally a computerized technique to track accounting transactions in combination with other information resources. Nguyen and Nguyen (2020) referred to the system of accounting information as a gathering of physical as well as non-physical constituents that are interrelated and conjoined with each other in harmony to handle financial and accounting data. A good system of accounting information consists of four apparatuses: information technology, persons, procedures and configurations, all of which can be assembled in two subsystems: technical and social subsystems. Based on Nwinee et al. (2016), the system of accounting information recently has tended to be a system of information that does not stop at limits of financial information and data, but it comprises descriptive and qualitative information that is valuable for making business decisions; whereas, Grande et al. (2011) defined the system of accounting information as a practice that, when incorporated into systems of information technology, are intended to enable companies in managing and controlling their economic-financial issues. The resultant information can be employed internally by managers or externally by other stakeholders. Grounded on Tilahun (2019), the system of accounting information can be defined as a technique to support directors to plan and control businesses by offering related and dependable information for them to make good business decisions. It is argued the purposes of accounting information systems are not only to make economic reports, but also its role goes beyond this conventional viewpoint. The acceptance of accounting information systems in business did upsurge organizational operating effectiveness particularly in big corporations as well as better controlling of resources and good managing of expenses, which will augment organizational value (Saira et al., 2010). Besides, Grande et al. (2010) the system of accounting information can deliver figures on both tangible and planned data that will allow enterprises to start, plan and run businesses. The acceptance of accounting information systems in business takes a significant role in contributing to organizational added value (Sori 2009). The system of accounting information ought to be utilized in order to plan and manage businesses. Consequently, a full acceptance of accounting information systems in business is indispensable to fully achieve competitive advantages from these systems. Many of the related researchers have indicated the acceptance of accounting information systems in business likely results in a better quality of accounting information (Al-Hiyari et al., 2013; Azmi \& Sri, 2015; Suzan et al., 2020; Fitrios, 2016); whereas others claimed that both the acceptance of accounting information systems in business and accounting information quality could be determined by organizational culture (Ha, 2020; Azmi \& Sri, 2015; Nguyen \& Nguyen, 2020). Afterwards, it will discuss and clarify the relationships among organizational culture, the acceptance of accounting information systems in business and accounting information quality. Al-Hiyari et al. (2013) indicated that a poor quality of accounting information may have adverse effects on decision making. For instance, Bowen (1993) pointed out errors in inventory databases could result in incorrect business decisions by executives, leading to overstock as well as understock. This can severely affect organizational success as well as client contentment. Accounting information quality could be measured in four aspects: Accuracy, Timeliness, Completeness and Consistency (Xu, 2003). The study of Xu (2003) studied critical achievement aspects for accounting information quality. The research accepted and focused on four groups which are manufacturers, custodians, clients and directors. Based on Azmi and Sri (2015), organizational culture is referred to as shared meanings, patterns of beliefs, rituals, symbols and myths, which change gradually, the aim of which is to lessen human variability, control and shape workers' behavior within a firm and to resolve issues of external adaptation and internal integration. Saffold (1988) studied culture traits and organizational performance, indicating that organizational culture pervades organizational life in a way to affect all aspects of the firm. Organizational culture plays a vital role in creating managing behavior due to its internal foundation of the firm. Denison (2000) believed organizational culture is the elementary basis to develop values and beliefs of workers, managers, clients, investors, traders and other stakeholders. The research classified organizational culture into four elements: Mission, Involvement, Adaptability and Consistency. According to the viewpoint of Musa et al. (2019), organizational culture is a significant factor in improving managerial systems; so, it can support the firm to reach the best potential effectiveness. Sajady et al. (2008) stated active systems of accounting information could boost the quality of accounting statements. Then, Al-Hiyari et al. (2013) acclaimed inclusive training programs to acquire necessary knowledge in the system of accounting information. Additionally, upper managers ought to support the acceptance of accounting information systems in business to get full benefits from these systems. Azmi and Sri (2015) tried to scrutinize the influencers of the acceptance of accounting information systems in business and accounting information quality. The empirical results indicated the acceptance of accounting information systems in business is significantly connected with accounting information quality. Fitrios (2016) analyzed the link between the acceptance of accounting information systems in business and accounting information quality. The 
findings provided significant support for the association between the acceptance of accounting information systems in business and accounting information quality. Suzan et al. (2020) suggested that the system of accounting information within a company can add value to the company, such as accurate and timely information in order to perform key activities in the value chain effectively and efficiently, improve quality and improve efficiency. They found that in several organizations in Indonesia, the system of accounting information had not been qualified, which leads to a lack of qualified accounting information.

From the standpoint of accounting information systems in business, Laudon and Laudon (2015) referred to organizational culture as an influential uniting force which confines political conflict as well as stimulates shared understandings. Rapina (2014) showed organizational culture could influence the acceptance of accounting information systems in business and accounting information quality as well. The connections from organizational culture to the system of accounting information in business and accounting information quality are highlighted and organizational culture has an effect on accounting information quality as well as the system of accounting information in business. In addition, Ha (2020) indicated organizational culture is one of the factors that influence the system of accounting information. Organizational culture positively affects the acceptance of accounting information system (Indeje \& Zheng, 2010). To design and adopt the system of accounting information in business, it is required to recognize and understand the norms, values and beliefs of a firm. Organizational culture is regarded as the basis for the best functioning system of accounting information in business (Kwarteng \& Aveh, 2018). Therefore, organizational culture affects the acceptance of accounting information systems in business. Overall, it can suggest that organizational culture influences the acceptance of accounting information systems in business and accounting information quality that is in turn determined by the acceptance of accounting information systems in business. Moreover, anchored in the propositions of Baron and Kenny (1986), it is proposed that the acceptance of accounting information systems in business could intervene in the relationship between organizational culture and accounting information quality. Grounded on the overview of the abovementioned discussions, the current research could conjecture the following research hypotheses:

$\mathrm{H}_{1}$ : Organizational culture can affect the acceptance of accounting information systems in business.

$\mathrm{H}_{2}$ : Organizational culture could determine accounting information quality.

$\mathrm{H}_{3}$ : The acceptance of accounting information systems in business likely influences accounting information quality.

$\mathrm{H}_{4}$ : The acceptance of accounting information systems in business likely mediates the relationship between organizational culture and accounting information quality.

\section{Research Methodology}

\subsection{Instruments}

In this research, three main factors are employed for analyses, which are organizational culture, the acceptance of accounting information systems in business and accounting information quality. These main factors are computed as follows. Based on Ha (2020), this study calculates "Organizational culture"- OC on four variables: (1) Mission- MI is composed of three items; (2) Involvement- IN is formed from three items; (3) Adaptability- AD comprises three items; (4) Consistency- CO is created from three items. These items are measured with a five-point scale. Based on Ismail (2009) and Nguyen and Nguyen (2020), "The acceptance of accounting information systems in business"- AB is assessed on 18 items: (1) General ledger; (2) Cost accounting; (3) Accounts receivable; (4) Financial accounting; (5) Accounts payable; (6) Financial analysis; (7) Billing; (8) Budgeting; (9) Order entry; (10) Project management; (11) Purchasing; (12) Production variances; (13) Inventory; (14) Budget variances; (15) Production planning and control; (16) Modeling; (17) Payroll; (18) Personnel management. These items are measured with a five-point scale. Grounded on Xu (2003) and Al-Hiyari et al. (2013), "Accounting information quality"- QI is evaluated on four dimensions: Accuracy- QI1, Timeliness- QI2, Completeness- QI3 and Consistency- QI4. These dimensions are measured with a five-point scale.

\subsection{Data collection}

Ho Chi Minh Stock Exchange and Ha Noi Stock Exchange were used to choose publicly listed enterprises for gathering the research data. There were 344 listed firms in Ho Chi Minh Stock Exchange and 366 in Ha Noi Stock Exchange, totally composed of 710 listed firms for collection. The primary solicitations were applied to acquire replies from managers in managerial accounting. A manager involved in managerial accounting was selected for each targeted firm. 710 questionnaires were distributed. Nevertheless, there are only 322 good replies with sufficiently required information for the current article.

\subsection{Analytic technique}

First of all, the reliability and factor analyses were used to decide the validity and reliability of the items. The connections among the explanatory variables are subsequently considered to check for multicollinearity in the research model. Subsequently, multiple regression analyses were employed to investigate the causal relationships. Lastly, the procedures supported by Aroian (1947) were utilized to test the statistical significance for the mediation of the acceptance of accounting information systems in business on the causal linkage from organizational culture to accounting information quality.

\section{Results}

The figures for the validity and reliability analyses are shown in Table1. All of the total connections obtain the values greater than the 0.5 level. The Cronbach $\alpha$ s are all more than the 0.7 threshold. Furthermore, all of the communalities surpass the 0.5 limits. Additionally, all of KMO (the Kaiser-Meyer-Olkin measures of sampling adequacy) exceed the 0.7 level. These figures designate all of the factors that meet the validity and reliability of scales. Hereafter, the variables utilized in analyses are 
dependably retained for the research (Hair et al., 2012). Multicollinearity leads to a truly severe consequence, as it raises standard errors; thereby frequently misleads findings. Therefore, the problem of multicollinearity should be tested by performing the correlating technique to scrutinize the connections among the Independent factors. The findings are delivered in Table 2. All of the connections are less than the 0.7 threshold, indicating there does not exists the problem of multicollinearity in the research model (Kennedy, 1992). Regression analyses are exhibited in Table 3. With regard to the causal influence of organizational culture on the acceptance of accounting information systems in business, as being shown in Model1, organizational culture positively influences the adoption of accounting information systems in business at the $1 \%$ significance level. The fit of the model is significant at the $1 \%$ threshold with $\mathrm{F}$ of 14.293 and $\mathrm{R}^{2}$ of $40.3 \%$, implying that organizational culture explains $40.3 \%$ of variation in the acceptance of accounting information systems in business. The effect of organizational culture on the acceptance of accounting information systems in business attains the 0.258 estimation. The estimate of DurbinWatson of 1.952 that ranges between du and $(4-\mathrm{du})$; consequently, it could suggest no autocorrelation in the research model. Additionally, the 0.29 value of $\chi^{2}$ with the significance level of 0.648 larger than the $10 \%$ threshold shows no heteroskedasticity in the analyzed data. Generally, the fit of the model is appropriate to the research model. As regards the relationship between organizational culture and accounting information quality, the results are displayed in Model 2 and Model 3. Organizational culture positively determines accounting information quality at the $1 \%$ significance level. The fit of models are significant at the $1 \%$ threshold with $\mathrm{F}$ of 34.118 or 19.431 . The $39.6 \% \mathrm{R}^{2}$ implies that organizational culture explains $39.6 \%$ of variation in accounting information quality. The effect of organizational culture on accounting information quality obtains the 0.290 or 0.268 estimates. The 1.998 or 1.956 estimations of Durbin-Watson that range between du and ( $4-\mathrm{du})$; indicating no autocorrelation in the research models. Additionally, the 0.98 or 0.07 values of $\chi^{2}$ with the significance levels of 0.312 or 0.799 larger than the $10 \%$ threshold demonstrate that the models get no heteroskedasticity. Overall, the model fits well to the research data.

Table 1

Validity and reliability analyses

\begin{tabular}{|c|c|c|c|c|}
\hline Dimension & Total Connection & Cronbach $\alpha$ & Communality & $\mathrm{KMO}$ \\
\hline MI1 & .665 & \multirow{3}{*}{.824} & .626 & \multirow{3}{*}{.815} \\
\hline MI2 & .653 & & .608 & \\
\hline MI3 & .648 & & .616 & \\
\hline IN1 & .692 & \multirow{3}{*}{.835} & .668 & \multirow{3}{*}{.862} \\
\hline IN2 & .657 & & .632 & \\
\hline IN3 & .739 & & .698 & \\
\hline $\mathrm{AD} 1$ & .713 & \multirow{3}{*}{.843} & .666 & \multirow{3}{*}{.878} \\
\hline $\mathrm{AD} 2$ & .678 & & .685 & \\
\hline AD3 & .771 & & .735 & \\
\hline $\mathrm{CO} 1$ & .723 & \multirow{3}{*}{.852} & .696 & \multirow{3}{*}{.879} \\
\hline $\mathrm{CO} 2$ & .710 & & .693 & \\
\hline $\mathrm{CO} 3$ & .610 & & .573 & \\
\hline $\mathrm{AB} 1$ & .628 & \multirow{18}{*}{.802} & .593 & \multirow{18}{*}{.850} \\
\hline AB2 & .625 & & .588 & \\
\hline $\mathrm{AB} 3$ & .611 & & .638 & \\
\hline $\mathrm{AB} 4$ & .697 & & .662 & \\
\hline AB5 & .700 & & .664 & \\
\hline AB6 & .676 & & .630 & \\
\hline $\mathrm{AB} 7$ & .710 & & .673 & \\
\hline AB8 & .743 & & .713 & \\
\hline $\mathrm{AB} 9$ & .579 & & .544 & \\
\hline $\mathrm{AB} 10$ & .623 & & .603 & \\
\hline AB11 & .632 & & .610 & \\
\hline $\mathrm{AB} 12$ & .566 & & .530 & \\
\hline $\mathrm{AB} 13$ & .635 & & .613 & \\
\hline $\mathrm{AB} 14$ & .638 & & .577 & \\
\hline AB 15 & .707 & & .677 & \\
\hline AB16 & .788 & & .779 & \\
\hline $\mathrm{AB} 17$ & .743 & & .720 & \\
\hline AB18 & .624 & & .566 & \\
\hline QI1 & .800 & \multirow{4}{*}{.876} & .803 & \multirow{4}{*}{.865} \\
\hline QI2 & .836 & & .842 & \\
\hline QI3 & .826 & & .833 & \\
\hline QI4 & .731 & & .713 & \\
\hline
\end{tabular}

The linkage between the acceptance of accounting information systems in business and accounting information quality are analyzed in Model3. The acceptance of accounting information systems in business is positively related to accounting information quality, where the former is a determinant of the latter. The link is significant at the $5 \%$ level with the 0.085 coefficient. The model obtains the goodness of fit at the $1 \%$ threshold with $\mathrm{F}$ of 19.431 and $\mathrm{R}^{2}$ of $40.9 \%$, implying that organizational culture and the acceptance of accounting information systems in business explain $40.9 \%$ of variation in accounting information quality. The 1.956 estimate of Durbin-Watson that range between du and $(4-\mathrm{du})$, which demonstrates no autocorrelation in the analyzed data. Additionally, the 0.07 value of $\chi^{2}$ with the significance level of 0.799 greater than the $10 \%$ threshold reveals that the model attains no heteroskedasticity. Therefore, the fit of the model is proper to the research model. The 
aforementioned findings offer statistical support for the research hypotheses $\left(\mathrm{H}_{1}, \mathrm{H}_{2}\right.$ and $\left.\mathrm{H}_{3}\right)$, where organizational culture affects the acceptance of accounting information systems in business and accounting information quality as well; whereas the acceptance of accounting information systems in business determines accounting information quality.

Table 2

Correlations among the explanatory variables

\begin{tabular}{cccc}
\hline & OC & AB & QI \\
\hline OC & 1 & .207 & 1 \\
AB & & .310 & .172 \\
QI & & 1 & \\
\hline
\end{tabular}

For the mediating influence, the results are demonstrated in Table 3. According to Table 3, the influence of organizational culture on accounting information quality decreases, when the acceptance of accounting information systems in business is entered into the model (a decline in the impact from 0.290 to 0.268). Furthermore, the acceptance of accounting information systems in business also statistically affects accounting information quality at the $5 \%$ significance level. In concurrence with Baron and Kenny (1986), it could recommend the acceptance of accounting information systems in business likely plays a mediating role between organizational culture and accounting information quality.

Table 3

Regressions Analyses

\begin{tabular}{|c|c|c|c|c|c|c|c|c|c|c|c|c|}
\hline Model & Dependent factor & Independent factor & $\beta$ & Std. Error & $\mathrm{t}$ & $\mathrm{P}_{\text {value }}$ & $\begin{array}{l}\text { Durbin- } \\
\text { Watson }\end{array}$ & $\chi^{2}$ & $\mathrm{P}_{\text {value }}$ & $\mathrm{R}^{2}$ & $\mathrm{~F}$ & $\mathrm{P}_{\text {value }}$ \\
\hline \multirow{2}{*}{1} & \multirow{2}{*}{$\mathrm{AB}$} & Constant & 1.507 & .270 & 5.589 & .000 & \multirow{2}{*}{1.952} & \multirow{2}{*}{.29} & \multirow{2}{*}{.648} & \multirow{2}{*}{.403} & \multirow{2}{*}{14.293} & \multirow{2}{*}{.000} \\
\hline & & $\mathrm{OC}$ & .258 & .068 & 3.781 & .000 & & & & & & \\
\hline \multirow{2}{*}{2} & \multirow{2}{*}{ QI } & Constant & 2.489 & .196 & 12.688 & .000 & \multirow{2}{*}{1.998} & \multirow{2}{*}{.98} & \multirow{2}{*}{.312} & \multirow{2}{*}{.396} & \multirow{2}{*}{34.118} & \multirow{2}{*}{.000} \\
\hline & & OC & .290 & .050 & 5.841 & .000 & & & & & & \\
\hline \multirow{3}{*}{3} & \multirow{3}{*}{ QI } & Constant & 2.362 & .204 & 11.551 & .000 & \multirow{3}{*}{1.956} & \multirow{3}{*}{.07} & \multirow{3}{*}{.799} & \multirow{3}{*}{.409} & \multirow{3}{*}{19.431} & \multirow{3}{*}{.000} \\
\hline & & $\mathrm{OC}$ & .268 & .050 & 5.312 & .000 & & & & & & \\
\hline & & $\mathrm{AB}$ & .085 & .040 & 2.094 & .037 & & & & & & \\
\hline
\end{tabular}

The procedures presented by Aroian (1947) are employed to test the statistical significance for this mediating effect. The findings are displayed in Table4. According to the empirical findings, the acceptance of accounting information systems in business statistically interferes with the causal link between organizational culture and accounting information quality at the $5 \%$ level with the 1.9697 value of $z$. The coefficient of $\beta$ gets the 0.0246 value with the 0.0125 level of standard error. Generally, the findings suggest the acceptance of accounting information systems in business partially mediates between the causal relationship from organizational culture to accounting information quality. Hence, the hypothesis H4 is statistically supported.

Table 4

The results of the mediating role of $\mathrm{AB}$

\begin{tabular}{ccccc}
\hline Relationship & $\beta$ & Std. Error & $Z_{\text {value }}$ & $P_{\text {value }}$ \\
\hline OC and QI & .0246 & .0125 & 1.9697 & .048 \\
\hline
\end{tabular}

\section{Conclusion}

The effects of organizational culture on the acceptance of accounting information systems in business and on accounting information quality as well as the influence of the acceptance of accounting information systems in business on accounting information quality have been discussed and explored by prior research; however they have been often analyzed in separate research models. The current research examines the relations in a combined research model in Vietnamese firms, which has been overlooked. Especially, the current work is one of the first projects to scrutinize how the acceptance of accounting information systems in business intervenes in the causal linkage from organizational structure to accounting information quality. The empirical findings reveal that organizational culture has effects on the acceptance of accounting information systems in business and on accounting information quality that is in turn determined by the acceptance of accounting information systems in business. These results are consistent with previous research on the relationships among organizational culture, the acceptance of accounting information systems in business and accounting information quality. Furthermore, the mediating role of the acceptance of accounting information systems in business is highlighted in this research, where the acceptance of accounting information systems in business declines the direct causal linkage from organizational culture to accounting information quality. Part of the effect is transmitted through the factor "the acceptance of accounting information systems in business". The empirical findings could help executives in developing economies like Vietnam to better understand the complex linkages among organizational culture, the acceptance of accounting information systems in business and accounting information quality in the business environment. As a result, they can deliver better business decisions on applying appropriate 
types of culture as well as suitable accepting levels of accounting information systems in business; so that their firms could attain the best potential effectiveness.

\section{References}

Al-Hiyari, A., AL-Mashre, M.H.H., Mat, N.K., \& Alekam, J.M. (2013). Factors that affect accounting information system implementation and accounting information quality: A survey in University Utara Malaysia. American Journal of Economics, 3(1), 27-31.

Aroian, L.A. (1947). The probability function of the product of two normally distributed variables. Annals of Mathematical Statistics, 18(2), 265-271.

Azmi, F., \& Sri, M. (2015). Factors that affect accounting information system success and its implication on accounting information quality. Asian Journal of Information Technology, 14(5), 154-161.

Baron, R.M., \& Kenny, D.A. (1986). The moderator-mediator variable distinction in social psychological research: Conceptual, strategic, and statistical considerations. Journal of Personality and Social Psychology, 51(6), 1173-1182.

Bowen, P.L. (1992). Managing data quality in accounting information systems: A stochastic clearing system approach (Doctoral dissertation, The University of Tennessee), USA.

Denison, D.R. (2000). Organizational culture: Can it be a key lever for driving organizational change. The International Handbook of Organizational Culture and Climate, 18(4), 347-372.

Fitrios, R. (2016). Factors that influence accounting information system implementation and accounting information quality. International Journal of Scientific \& Technology Research, 5(4), 192-198.

Grande, E., Estebanez, R., \& Colomina, C. (2010). The impact of Accounting Information Systems (AIS) on performance measures: empirical evidence in Spanish SMEs. The International Journal of Digital Accounting Research, 11(11), 25 - 43.

Ha, V.D. (2020). Impact of organizational culture on the accounting information system and operational performance of small and medium sized enterprises in Ho Chi Minh City. The Journal of Asian Finance, Economics, and Business, 7(2), 301-308.

Hair, J.F., Black, W.C., Babin, B.J., Anderson, R.E., \& Tatham, R.L. (2012). Multivariate Data Analysis. Ed, New Jersey: Pearson Prentice Hall, USA.

Huynh, Q.L., Nguyen, T.T., Huynh, T.K., Duong, T.A., \& Le Thi, T.L. (2020). The Effects of Organizational Culture on Human Resources Management: A Study on Vietnamese Publicly Listed Enterprises. Asian Economic and Financial Review, 10(7), 885-894.

Indeje, W.G., \& Zheng, Q. (2010). Organizational Culture and Information Systems Implementation: A Structuration Theory Perspective. Sprouts: Working Papers on Information Systems, 10(27). http://sprouts.aisnet.org/10-27.

Ismail, N.A. (2009). Factors influencing AIS effectiveness among manufacturing SMEs: Evidence from Malaysia. The Electronic Journal of Information Systems in Developing Countries, 38(1), 1-19.

Kennedy, P. (1992). A Guide to Econometrics. 3rd ed, MIT Press, Cambridge, MA, USA.

Kwarteng, A., \& Aveh, F. (2018). Empirical examination of organizational culture on accounting information system and corporate performance: Evidence from a developing country perspective. Meditari Accountancy Research, 26(4), 675-698.

Laudon, K.C., \& Laudon, J.P. (2015). Management information systems. Upper Saddle River: Pearson, New Jersey, USA.

Musa, O.B., Salehuddin, S.N.B., Ani, Z.B.C., \& Ali, M.A.B.M. (2019). The impact of organizational factors towards safety management system performance of the Royal Malaysian Air Force. Academy of Strategic Management Journal, 18(6), 1-6.

Nguyen, H., \& Nguyen, A. (2020). Determinants of accounting information systems quality: Empirical evidence from Vietnam. Accounting, 6(2), 185-198.

Nwinee, K., Akpos, Y., Vincent, N., \& Ibinabo, T. (2016). Impact of accounting information system on organizational effectiveness: A study of selected small and medium scale enterprises in Woji- Portharcourt. International Journal of Research, 3(1), 974-982.

Rapina, R. (2014). Factors influencing the quality of accounting information system and its implications on the quality of accounting information. Research Journal of Finance and Accounting, 5(2), 148-154.

Romney, M.B., \& Steinbart, P.J. (2015). Accounting Information Systems. $13^{\text {th }}$ ed. Pearson Education Limited, USA.

Saffold III, G.S. (1988). Culture traits, strength, and organizational performance: Moving beyond "strong" culture. Academy of Management Review, 13(4), 546-558.

Saira, K., Zariyawati, A., \& Annuar, N. (2010). Information system and firms' performance: the case of Malaysian small medium enterprises. International Business Research, 3(4), 28-35.

Sajady, H., Dastgir, M., \& Nejad, H.H. (2008). Evaluation of effectiveness of accounting information systems. International Journal of Information Science and Technology, 6(2), 49-59.

Sori, M. (2009). Accounting Information Systems (AIS) and Knowledge Management: A Case Study. American Journal of Scientific Research, 4(4), 36-44.

Soto-Acosta, P., Popa, S., \& Palacios-Marqués, D. (2016). E-business, organizational innovation and firm performance in manufacturing SMEs: an empirical study in Spain. Technological and Economic Development of Economy, 22(6), 885-904.

Suzan, L., TSudrajat, J., \& Daud, Z.M. (2020). Accounting information systems as a critical success factor for increased quality of accounting information. Revista ESPACIOS, 41(15), 2-8.

Tilahun, M. (2019). A Review on Determinants of Accounting Information System Adoption. Science Journal of Business and Management, $7(1), 17-22$.

$\mathrm{Xu}$, H. (2003). Critical success factors for accounting information systems data quality (Doctoral dissertation, University of Southern Queensland), Australia.

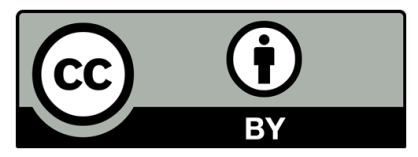

(C) 2021 by the authors; licensee Growing Science, Canada. This is an open access article distributed under the terms and conditions of the Creative Commons Attribution (CC-BY) license (http://creativecommons.org/licenses/by/4.0/). 